\title{
ONE STEP FORWARD, TWO STEPS BACK THE SERBIAN PATH TO EUROPE AT THE BEGINNING OF THE TWENTY-FIRST CENTURY
}

\section{MLADENA PRELIĆ}

In most eastern European countries, consensus on EU integration was reached relatively easily. In Serbia, however, the political and intellectual elites are still reluctant to make definite decisions with respect to EU integration. Thispaper analyzes public discourse, its possible contextual meanings, and its relation to the public opinion polls on this issue. The findings offer a particular perspective on the slow and still far from completed process of Serbian integration into the European Union.

Keywords: Serbia, modernization, EU integration, public discourse, public opinion
Za večino vzhodnoevropskih držav je značilno, da so razmeroma zlahka dosegle javni konsenz o integraciji v Evropsko unijo. V Srbiji pa politične in intelektualne elite še vedno omahujejo o dokočni odločitvi za evropsko integracijo. $V$ prispevku avtorica analizira javne diskurze, njihove možne pomene in jih primerja z rezultati raziskav javnega mnenja, ki obravnavajo ta vprašanja. Avtoričina namera je z izbranega gledišca nekoliko osvetliti nedokončan in počasen proces vključevanja Srbije v Evropsko unijo.

Ključne besede: modernizacija, Srbija, evropska integracija, javni diskurzi, javno mnenje.

The question that has accompanied Serbian society throughout most of its modern history is whether Serbia can and should be a European country, in the sense of belonging to the developed democratic world. This question was revived in Serbia's contemporary crisis, which began with the fall of communism and dissolution of Yugoslavia in the 1980s and 1990s, raising questions (not only in Serbia) about (re)defining national identity and the future direction of the country's development. Today this question is formulated as whether, how, and when Serbia should become part of the European Union. ${ }^{1}$

\section{THE OTHER EUROPE: SYMBOLIC GEOGRAPHY}

The term Europe is very old, originating with the Ancient Greeks, but what this term has denoted for thousands of years has not always been the same. Europe must therefore be understood as a developing term. Its historical geographical meaning has also changed over

1 This paper is based on the author's “insider's knowledge” as a member of Serbian society, as well as systematic monitoring of certain media. Four television channels were selected - RTS (Serbian state TV), Studio B (Belgrade city TV), B92 (a private TV channel well known for its opposition to the regime in the 1990s), and BK TV (owned by one of the Serbian business oligarch (tajkun), who was close to that regime) - and several segments of time from July 2002 to February 2009 were analyzed. An earlier, shorter, and somewhat different version of this article was published in Serbian (Prelić 2006). 
time (Šmale 2002: 41-58). Today, most geographic doubts have been resolved; however, the boundaries of Europe in a cultural sense are still uncertain and subject to redefinition. This uncertainty becomes clearer if one notes that Europe is not only a geographical term, but also a normative term. The roots of this term in today's meaning originate from the Enlightenment, when certain political and cultural centers located in Western Europe defined the notion of progress and equated it with Europe. Thus the term also received a geographical projection, in which imagined pairs of contradictions such as progress versus backwardness, European versus non-European spirit, European versus non-European tradition, and culture versus values were projected onto the outer world as contrasts identified with specific territories: Europe versus Asia, Europe versus the Orient, Europe versus America, and so on (Subotić 2003: 79-82). In these cases, the Other is situated outside Europe. Apart from the external Other, however, the normative term Europe also establishes an inner Other because the cultural, social, or political reality of the territories that geographically belong to the European continent can also differ from Europe as a normative term.

For territories that geographically belong to Europe but whose (cultural) belonging to Europe is questioned, the case of Russia (although territorially partly in Asia) is particularly characteristic; this phenomenon also extends to all of Eastern Europe and particularly the Balkans (Šmale 2002: 92-93). ${ }^{2}$ The boundaries of the other Europe have not always been the same, ${ }^{3}$ and throughout history various names have been used for it: Eastern Europe, European Turkey, southeastern Europe, Euroasia, the Balkans, the Western Balkans, and so on. ${ }^{4}$ During the 1990s, the Balkans was revitalized as the almost exclusive Other of Europe; with the fall of the Berlin Wall, the Cold War polarization of Western Europe versus Eastern Europe disappeared, but the wars in the former Yugoslavia renewed the "Orientalizing" discourse surrounding the Balkans. ${ }^{5}$ Although today there might be an "ill-tempered accommodation" that the Balkans is in the West, the alien and symbolically lower nature of the Balkans is still reflected in stereotypes about its primitivism, savagery, and poverty (Fleming 2001: 26-27). In recent years, frequently under the influence of Edward Said (Sajd 2000), ${ }^{6}$ the relation of Europe towards the Balkans

2 On the origin of the term and the identity of Eastern Europe, see Wolff (1994). It is interesting to note that, although in the entirely different context of their long-term and deep-rooted national tradition, many Western European countries also face problems with European identity (Domenak 1991: 41-58).

3 An example of the redefinition of cultural boundaries of the self and the other Europe is obvious in the term central Europe (Subotić 2003).

4 It is notable that Serbia has been included in each of these entities.

5 The Balkans itself does not always have stable borders in symbolic geography. Here I state the opinion of Maria Todorova, according to which the Balkans is a part of Europe that was long under Turkish rule and whose culture is marked by Ottoman heritage (Todorova 1999: 60-62).

6 In addition to Said's works, the works of Larry Wolff and Maria Todorova gave particular incentive to this direction; in recent times, there has been an entire series of papers on this topic, such as Vesna Golsvorti (2005), Milica Bakić-Hayden (1998), Marko Živković (2001), Stef Jansen (2001), and Božidar Jezernik (2007). 
has often been interpreted from the aspect of Orientalism. ${ }^{7}$ Balkanism and Orientalism, however, are not entirely equal. In contrast to the Orient, the alien nature of the Balkans in comparison to Europe does not stem from its remoteness, but from its proximity. Not only in the geographical sense, but also in the cultural and historical sense, the Balkans is a part of Europe, although stigmatized and symbolically polluted by its poverty, relative backwardness, and traces of Oriental heritage. According to some authors, this is a divergence from Orientalism; apart from an actual colonial relation (which the Balkans has not experienced in such a way as, for example, Egypt or India), Orientalism assumes a distinct Other - different, incomprehensible, but fascinating in a way. Balkanism is characterized by a feeling of deep similarity, and the alienation stems from the unpleasantness caused by that similarity. Whereas the Orient, although in fact subordinated, is exotic, mystical, seductive, and rich at the level of imagination, for Europe the Balkans is something like a poor and disdained cousin, something to be ashamed of as a reminder of its own past and/or own hidden ugly side. The specificity of Balkan symbolic geography, discourse, and rhetoric comes from its bisection; that is, its liminality. It is Europe, and it is not Europe at the same time (Todorova 1999: 15-44).

\section{UNFINISHED MODERNIZATION, RELATIVE BACKWARDNESS, AND DIVIDED SOCIETY}

Since the Enlightenment, Western Europe has strengthened its position as more powerful not only than the rest of the non-European world, but also more powerful than Eastern Europe and the Balkans. The West created the frame of interpretation for the East, but also the frame in which the East, as subordinated, is self-reflected. The idea of the other Europe's lagging behind has been developing since the eighteenth century. However, this issue can also be approached from the opposite (or, conditionally, objective) side. If the parameters of progress and backwardness are accepted as real, then the issue of the otherness of Eastern Europe / the Balkans / Serbia becomes the issue of their actual backwardness, and not only symbolic representation and perception.

By many measures, Serbia (and the Balkans and Eastern Europe) is indeed not a modern country, and its efforts toward modernization in last two hundred years have been hindered - and not only from the outside, but also, or even primarily, from within the society itself. ${ }^{8}$

7 Orientalism is the prevailing pattern of cultural representation according to which Europe has the privileged status of defining itself as progressive, modern, and rational, and the Other (the Orient) as stagnant, obsolete, traditional, and mystical. It derives from an uncritically assumed essential dichotomy between East and West. Orientalism is a discourse, East and West are draft projects, and the boundaries of the Orient have changed through history, but the notion of the Orient as the essential "Other" of Europe is constant (Bakić-Hayden and Hayden 1992: 1-2).

8 Domestic historiography is increasingly richer in works that interpret failure to modernize through obstacles within Serbian society itself. Perhaps it is needless to emphasize that domestic historians 
Looking at this failure from the aspect of Serbian society, Serbia is a country of unfinished/ failed modernization, and the basic obstacle for a true "modernization breakthrough" is the very structure of that society, which at the beginning of Serbia's modern history consisted of only one layer: the peasantry. In its mentality, understanding of politics, society and state, national program, aspirations, and achievements, Serbian society (elites included) remained prisoner to such conditions throughout the largest part of its history. ${ }^{10}$ The basic cultural matrix - the cooperative egalitarianism of poor peasants with a patriarchal consciousness - precludes the profound step to modernity; that is, the creation of a socially stratified society with division of power, stable institutions, and rule of law (Perović 2006). However, ever since the beginning of the nineteenth century, liberated Serbia (or at least part of its elites) have seen Serbia as a part of Europe. The great misunderstanding between Serbia and Europe lies in the fact that Serbia sees itself in Europe, in some periods of its recent history also investing great efforts to overcome the difference between itself and the developed world, yet these efforts turn out to be fragile and superficial, and Serbia remains weak, relatively backward, and unaccepted by the outside world. Its usually only virtual and superficial, but not essential, achievements in modernization are exposed to permanent inner and outer jeopardy (Noris 2002). Modernizers often end up as victims of conservative currents. ${ }^{11}$ The problem of failed modernization is first of all the problem of the Serbian elites. They are partly weak and not rooted in broader social layers, and, moreover, to a large extent are very close to the people they originated from. They are unable to essentially differentiate themselves, and so they have not succeeded in carrying out the modernization project. Frustrated by this failure, they have split into pro-western and anti-western factions and are fighting among themselves, and this division in no way contributes to the success of endeavors to modernize the country (Perović 2006).

Apart from these works regarding unfinished modernization, it is also interesting to note the works of economic historians, who interpret the lagging behind of the other Europe

themselves are sharply divided (not only on this issue, but it is very indicative) into groups that can tentatively by labeled as critical and national historians, so that recent historiography itself is an illustration of divided Serbian society, which is discussed in greater detail below.

9 For the most concise introduction to this sort of interpretation, see Perović (2006), Stojanović (2005), and Obradović-Popović (2006). It has already been stated that critical historiography in Serbia is increasingly richer, and that historiographic interpretation itself reflects many contemporary problems of Serbian society, but space does not permit more detailed commentary. For a synthetic study of the history of Serbia during the last two centuries, see Zundhausen (2008). Of course, Zundhausen's critical interpretation has resulted in reactions and polemics (cf. Politika, 26 January 2008, page 9).

10 An illustration of the lack of social differentiation of Serbian society is that both nineteenth-century dynasties that rose to throne in the first and second Serbian uprisings of 1804 and 1815 (Karađorđević and Obrenović) originated from the stratum of peasant-traders. This stratum played a specific role in the development of civil society in Serbia (cf. Antonijević 2007).

11 The most violent examples (but not the only ones) are certainly the victims of assassinations - the enlightened absolutist Prince Mihailo Obrenović (1823-1868) and Zoran Djindjić (1952-2003). Political violence, assassinations, and violent changes of power, together with various other modes of discontinued development, are prominent in Serbian history (Jovanović 2005). 
as a relative backwardness. They do not see the division into two Europes as a variant of internal colonialization that had been planned in advance. In their opinion, due to a series of unpredictable, very complex, multiple, and interrelated causes, the European West had economically, socially, and politically separated from the East by the Middle Ages and started to develop at unprecedented speed. Once started, this difference could no longer be overcome, and all attempts by the East to reach West by "copying the lesson" proved doomed from the very beginning because this lesson, due to the complexity and interdependence of numerous causes of social development, was impossible to copy, especially in societies that were not socially or historically ready for it (Chirot 1991). It is impossible to alter the relation between the center and the periphery within the determined frameworks of distribution of power as they are known today. The division that was created cannot be overcome without a profound change of the global system. The given framework, however, does not mean that the periphery should not develop - it must follow the center despite its peripheral position, otherwise it will sink into total backwardness. ${ }^{12}$

In the case of Serbia, it seems that there is a misunderstanding of the starting position, which leads to frustrations and the bipolarity of the elites toward those that, led by a specific feeling of mission, are making every effort to lead Serbia to the world in the shortest possible time, which ends in breakdown, or to those afraid of that world, perceiving it as hostile and thinking that they will not be able to retain their prestigious position in it. The frustration created by a peripheral position that cannot be overcome creates a polarization of the elites - one group has developed a resigned self-disdain and a feeling that Serbia is missing something, that Serbia will never be the "world," whereas another group is elaborating myths of Serbia's own greatness, of a genuine Europe that is allegedly situated exactly here, of the Balkans as the center of the world; that is, of Serbs as an extraordinary people whose greatness is denied by the "world" because of envy or vested interests.

The crises and trauma that Serbian society has been passing through since the 1980s are revitalizing deep social divisions and actualizing the metaphor of "two Serbias." The dissolution of Yugoslavia and the wars that ensued particularly emphasized this division, ${ }^{13}$ evoking all other historical divisions among the people of Serbia. Serbian society is today still an example of a divided society, without any consensus about the basic directions of its development and common social goals. The period of Zoran Djindjićs government

12 For example, by understanding its peripheral position and attempting to derive advantage from it by comprehending the periphery as an area of freedom and intensive exchange and communication (distance from the center and proximity of the border).

13 This was particularly clear among intellectuals of the "core" and "other" Serbia, particularly in relation toward Milošević's non-democratic rule, nationalism, and responsibility for the war in the former Yugoslavia during the 1990s. Regarding how intellectuals think about the "other" Serbia, see Čolović and Mimica (1992) and Popov (1996). Regarding the "treason of the intellectuals," which supported nationalism, see Dragović-Soso (2005). 
$(2001-2003)^{14}$ is a brief exception, which tragically ended with new hesitations and dilution of the problem ensuing after the elections of 2004.

The issue of the modernization of Serbia has remained open and problematic throughout its recent history (since 1804). It can be expounded in several core questions: is only westernization (i.e., Europeanization) modernization? If yes, is Serbian society capable of developing according to the Western pattern? Are Serbian elites genuinely and prevailingly committed to modernization and are they capable of carrying it out? In post-communism, the issue of whether Serbia should be a modern European country took on the form of a concrete question: Should and can Serbia join the EU?

\section{SERBIA'S RELUCTANT APPROACH TO EUROPE: FORMAL STEPS AND SOCIO-POLITICAL CONTEXT}

Although for ideological and economic reasons it could not be a member of the EU, the "second Yugoslavia" was in many aspects different from the other countries behind the iron curtain, with its people proud of the fact that their living standard was much more Westernlike than in any other communist country. The Yugoslavia of that time committed a certain amount of effort to establishing a partner relation with the European Economic Community. Commercial treaties between the EEC and the SFRY had been signed from 1970 onwards. ${ }^{15}$

The end of communism pushed Serbia (until recently part of Yugoslavia, and proud of being more open and progressive than other Eastern European countries and, at least from the external view, neither East nor West but somewhere in between) into complete political and social disarray and, among other things, to the very rear of European integration processes.

Not breaking with communism, which was departing from the historical scene and non-democratic, combined with the extremely populist character of the regime that enthroned itself during the $1990 \mathrm{~s}^{16}$ but was inept at solving any essential problem, led to Serbia being perceived as an authoritarian, autistic, non-democratic country. The wars in the former Yugoslavia added a heavy stigma of Serbia being the aggressor and the main culprit for the bloody dissolution of the country. The dissolution was preceded by a weak attempt in 1988 to overcome the crisis by opening the possibility of Yugoslavia entering the EEC, but that attempt failed. (Ranković 2005) After 1991, the European Community started carrying out restrictive measures toward Serbia and Montenegro, followed by sanc-

${ }_{14}$ In this short period, at the head of the government of Serbia there was a person that understood the complexity of the task and was ready to lead the process of changes, with support up to a certain point for that process coming both from society itself and from outside. However, the moment was missed and the energy that existed at that time increasingly crumbled later on.

15 Website of the Serbian government's EU Integration Office (http://www.seio.gov.rs).

16 The regime was personified in Slobodan Milošević, but it comprised the entire layer of people that gained financial and political power at that time. 
tions in 1992, which gradually started being lifted in 1995 with the signing of the Dayton Agreement. Serbia's conflict with the world was, however, still going on, culminating in the conflict with NATO in 1999, when Serbia and Montenegro were bombarded for three months.

Years of isolation and war have left severe consequences on Serbian society. The wars in the former Yugoslavia represented a specific mode of transition for Serbia. ${ }^{17}$ Simultaneously, and inherent to the aforementioned process of transition through war, society suffered overall impoverishment, criminalization, and destruction of many of its aspects. ${ }^{18}$

The changes that developed around the end of 2000 created a possibility for an essential transformation of Serbia. At the same time, it reopened to the world. Specifically, when speaking of formal steps for Serbia approaching the EU, this means the commencement of the Stabilization and Association Process, the first clear sign of which was the establishment of the Joint Consultative Task Force for EU Association in July 2001. The period from July 2002 to July 2003 saw the Enhanced Permanent Dialogue being held with EU representatives. ${ }^{19}$ The reform government headed by Zoran Djindjić, which came to power after the elections and changes at the end of 2000, inherited huge problems; nevertheless, it defined modernization of the country and the road to the EU as one of its priorities. ${ }^{20}$ To this end, the government's measures pertained particularly to economics.

The assassination of reformist Prime Minister Zoran Djindjić on 12 March 2003 was a tremendous shock and huge loss for all EU-oriented people and social forces in Serbia. Nonetheless, Serbia was admitted to the Council of Europe quickly afterwards. An extensive campaign to fight organized crime ensued immediately after the assassination of the prime minister. For a time, it seemed that the tragic event would not mean the termination of the Europeanization process. By the end of the year, however, the reform government encountered problems and had to step down from power under pressure from the opposition and the public.

The new government, headed by Vojislav Koštunica, still declared its commitment to Serbia's EU path, although with certain caution. Some steps were made toward this end. For example, on 7 February 2004, the act on European Partnership with Serbia and Montenegro $^{21}$ entered into force. ${ }^{22}$ The year 2004 saw the establishment of two important

17 It established a kind of business oligarchy (tajkuns) with money of suspicious origin and with much hidden power.

18 Regarding the destructive processes that gripped Serbian society during the 1990s and their various aspects, see Lazić (1994, 1994b, 2000), Antonić (2002), and Bolčić and Milić (2002).

19 See: http://www.seio.gov.rs.

20 The plan proclaimed by this government envisaged that Serbia should meet conditions for candidacy by 2004 , and become a full member of the EU by 2010. See, for example, Djindjić (2005), particularly pp. 52-54.

${ }^{21}$ Serbia-Montenegro was the successor state of the "small" Yugoslavia, which dissolved into two independent states in June 2006.

22 This document regulated all relations between Serbia-Montenegro and the EU before the Stabilization and Association Agreement was signed (http://www.seio.gov.rs). 
governmental institutions - the Commission for Coordination of the EU Accession Process and the Council for European Integration Processes of the Government of the Republic of Serbia - as well as the opening of the government's EU Integration Office. ${ }^{23}$ In October the same year, the Serbian Assembly adopted the Resolution on EU Accession, which defines EU entry as the state's highest and undisputable priority. In April 2005, Serbia-Montenegro received a Feasibility Study, in July the government's National Strategy of Serbia for Serbia-Montenegro's EU Accession was announced, and negotiations on stabilization and association started in October the same year. ${ }^{24}$

In spite of these very concrete developments, and the public proclamation of proEuropeanness, at a more subtle and less visible level a silent restoration of the former regime was underway, together with rekindling of national sentiments in a retrograde manner. As the result of these two-sided politics, the Serbian path to the EU was, after a short period of hope, again characterized by slowness, indecisiveness, and numerous delays. Negotiations were suspended by 3 May 2006 due to Serbia's insufficient cooperation with the Hague Tribunal. ${ }^{25}$

After the suspension of negotiations, the European issue was somehow put aside until the end of 2007. The political elite gave the impression that Serbia would, possibly, still move closer to Europe, but under its own terms (!), whereas this topic was not frequently broached in public. With the arrival of the new coalition, dominated by the Serbian Democratic Party (SDS), with Vojislav Koštunica yet again as the head of the government, the issue of renewal of negotiations with the EU was again emphasized, mostly due to the efforts of several prominent politicians and members of Serbian Democratic Party. In December 2007, almost on his own responsibility and with the criticism of coalition partners and anti-EU elements among the public, the SDS's minister in the government, Božidar Djelić, initialed the Stabilization and Association Agreement in Luxembourg. The beginning of the next year brought strong shocks related to Kosovo's declaration of independence ${ }^{26}$ temporarily strengthening nationalist rightwing elements. A major change in this respect occurred before the elections scheduled for 11 May 2008: on 29 April, Serbia signed the Stabilization and Association Agreement (although it is still not in force in EU institutions, it was ratified in the Serbian parliament on 9 September 2008). In the same period, an important contract was signed with Fiat on major investments planned for the automobile industry in Serbia. This put wind in the sails of the pre-election coalition "For a European Serbia," with the Serbian Democratic Party as its axis. The voters understood this election as a referendum on the EU, and rightwing, isolationist parties were defeated

23 See: http://www.seio.gov.rs. Due to complicated internal relations between Serbia and Montenegro, which hindered the common integration processes, a "dual track" approach was adopted for these two states; that is, that each of them would proceed toward the EU at its own pace.

24 See: http://www.seio.gov.rs.

25 Apart from this, EU partners see corruption at all levels and the unreformed judiciary as the biggest obstacle for Serbia's accession to the EU.

26 This happened on 17 February 2008. 
even where they had traditionally enjoyed strong bases. The SDS took over responsibility for EU integration. The very beginning of the term of office of the new government saw the arrest of the Hague fugitive Radovan Karadžić, which meant the fulfillment of one of three items for cooperation with the Hague Tribunal. Matters had moved from a standstill, or at least it seemed so.

To some extent, a shadow was cast on the landslide victory of the "For a European Serbia" parties by the coalition with the SPS (the party of Slobodan Milošević), which was explained by political pragmatism, but which was not accompanied by any distancing of the SPS from its previous policies. Likewise, the policy toward Kosovo bears significant traces of the policy led by Milošević. ${ }^{27} \mathrm{New}$ doubts arose with the "gas arrangement" with the Russian company Gazprom - the sale of the Naftna Industrija Srbije (Serbian Petroleum Industry) to the Russian company in an insufficiently transparent manner, which raised certain doubts and fears among the public that it would unnecessary lead Serbia into a long-term energy dependence on Russia. In recent months, problems in society have been further accumulating: due to an unclear situation in the National Assembly, where one of the two largest political parties did not participate in the election at all, ${ }^{28}$ and obstruction by part of the opposition, the parliament has lost both its legitimacy and respect. Elections, which are the only possible means to solve this, are not on the horizon. Power is being increasingly concentrated beyond the law and the constitution, in the hands of one person - the Serbian president. It seems that the ruling parties did not really set out to solve problems in society, which are in fact enormous. To mention only a few, these include the unreformed state security structures that survived from the former regime, corruption in the judiciary, lack of transparency in governance, irresponsible journalism, the particracy of politics (understanding society as the party's booty), and years of delay in passing systemic laws to create a foundation for social reforms, such as an act on the restitution of property. ${ }^{29}$

27 The problem of Kosovo and the Serbian policy toward it is a very large issue; space does not allow its discussion here. In brief, it could be said that this issue was largely abused for internal political manipulation, without a really constructive approach by official Serbian politics. Attempts to further manipulate this problem are turning out to be increasingly less beneficial. See, for example, Malešević (2008).

28 This occurred because the Radical Party had divided into two parties, with the larger part changing its name to the Serbian Progressive Party, and to some extent also changing its proclaimed political goals. Both parties are in the parliament, whose work is obstructed by the "old" Radical Party, dissatisfied because the Progressives (with the agreement of the ruling majority) kept the terms of office they received as Radical Party candidates.

${ }_{29}$ For a critical view of contemporary Serbian society, see, for example, episodes of Pešćanik 1-12. Pešcanik is a radio show broadcast for years on B92, known for its uncompromising critical oppositional attitude toward and criticism of every government. The creators of the show have been subject to various pressures, threats, and charges for years for their alleged radicalism (see also the Pešćanik website, http://www.pescanik.net). 
One after another, the ruling elites increasingly appeared to act as interest groups, with their only goal to remain in power for their own benefit as long as possible. ${ }^{30}$

Recently (in early March 2009), the highest echelons of power labeled the coupling of crime, politics, the judiciary, and business as the biggest problem in Serbian society. The media characterized this statement as very important, and the president emphasized what in fact is the biggest problem of society and publicly assumed responsibility for solving it. Will this remain only a nice sound bite, or will the near future show that a truly profound clearing of the society is underway? The reality of today's society in Serbia - the reality of a destroyed society ${ }^{31}$ - however, casts a shadow on achievability of this goal, even when there is the political will for it.

The profound destruction of society that occurred in Serbia during the 1990s represents the profound destruction of its institutions - state, economic, and cultural ones - and hence society itself. This means that people in Serbia en masse lived their everyday lives beyond and against the rules and norms of official, institutionalized society. This lifestyle was in fact a survival strategy within the burdensome daily life produced by the government - which, however, itself contributed further to the destruction of the society. "Parainstitutions" emerged in reality, concentrating significant social power, but without legitimacy and without oversight. Survival exhausted people in every respect, producing mass apathy and a "weak society." Therefore social normalcy in Serbia is being reestablished with difficulty and slowly, in spite of changes at the top level of power (which has often proved to be only superficial), and an internal driver of social reconstruction is difficult to find (Bolčić and Milić 2002: 10-11).

It seems that the pro-EU orientation in Serbia today is first of all receiving the verbal support of the political elites, whereas concrete moves are accompanied by hesitation. EU options are uncompromisingly advocated not only by some small political parties, some nongovernmental organizations, and public intellectuals that, because of this, still can be labeled as traitors, but also by several politicians in office, some governmental structures, and a layer of state bureaucrats in charge of carrying out reforms, who are attempting to bring the idea of integration closer to people as something positive for development, stability, security, good neighborly relations, living standards, market development, and democracy. However, it has often been doubtful whether they have the honest, and not only verbal, support of the rest of the politicians in power.

30 The period of Zoran Djindjićs government is certainly an exception, although some media even today make every effort to present a picture of him as a "criminalized politician."

31 Sociologists dealing with Serbian society since the 1990s characterize it, among other things, as “destroyed" (see Bolčić 1993: 27-37; Lazić 1994; Bolčić and Milić 2002). 


\section{ON THE VERGE OF THE NEW MILLENNIUM: CONTEMPORARY PUBLIC DISCOURSE ON SERBIA AND EUROPE}

The deep crisis that grasped Serbian society during the 1980s had numerous aspects, the issue of identity certainly being one of them. When it became clear that the earlier, multinational state would not be able to survive, in Serbia (as well as in the other countries and societies of the former Yugoslavia), among other things, the question of "Who are we?" arose in order to formulate a new project for a future based on recognition of Serbia's own (redefined) identity.

The regime that came to power in the early 1990s gave lip service to advocating European integration, but in its deeds it was extremely isolationist in relation to the outer world, and particularly the West. One important characteristic of domestic politics was populist nationalism, which inspired a mushrooming of identity discourse in that style, particularly in the media at the end of the 1980s and in the early 1990s (cf. Lazić 2000; Antonić 2002). Serbs (again) started to be depicted as the heirs of Byzantine spirituality, guardians of authentic European values (in contrast to materialistic or tired Europe, which had abandoned them), defenders of (ungrateful) Europe from Islam, as people with warrior and liberator traditions, proud, sound and vital residents of the Balkans, soft Slavic souls, "heavenly people" that voluntarily sacrificed themselves and renounced this world, choosing spiritual and Christian values - the empire of heaven.

Many ideas of Serbs from that period that were renewed, created, or redefined by politicians (i.e., populists that were in power and intellectuals that assigned themselves the task of the national awakening of the people), serving the function of national mobilization, followed by the destruction of Yugoslavia and war. The alleged Serbian national identity publicly and officially formulated at that time fit the isolationism of the regime - it sharply contrasted us and them, particularly Serbs versus the West, insisting on the stereotype of the Serbs as permanent victims and reaching its climax in the myth of the Serbs as the oldest civilized people of the world, the creators of the entire civilization of the "old world," known as Srbi, narod najstariji 'Serbs, the oldest nation' (cf. Luković-Pjanović 1990; Todorović 2005). The deep crisis of Serbian society in the 1990s led to some intellectuals, who did not identify themselves either with official politics or with officially promoted discourse on identity, starting to critically reexamine the myths about these "heavenly people" - which, in their interpretation, neglected the values of earthly life and the value of life itself, are authoritarian, are always in search of a leader, lack internal discipline, prefer to wage wars rather than work, masochistically celebrate their own defeats, were never entirely Christianized, have a cyclical rather than linear sense of time, and are obsessed with tradition and the past, but without actually knowing or preserving it, as people of short memory and undeveloped morality. This is only another illustration of the divided society of Serbia, a society that at one moment, in the early twenty-first century, reached a fragile consensus about its path to Europe - a consensus that was soon destroyed again. 
This is also proved by discourse in public speech after the changes of 2000, which were only briefly presented here.

After years of isolation, poverty, and war, under changed political circumstances after 5 October 2000, ${ }^{32}$ the country was opening up, and European integration became a realistic, although long-term possibility. That changed situation again imposed the need to answer the following question: "Who are we and what identity do we need for the new era, which direction are we going, and is a modern, European Serbia our goal?"

The politicians that then came to power within a very broad coalition ${ }^{33}$ achieved a consensus that joining the EU was necessary, and the leading parties declared a European Serbia as their goal. In his address at the Tenth Congress of the Serbian Democratic Party (SDS), for example, Prime Minister of Serbia and President of the SDS Zoran Djindjić said, among other things:

And we propose a national vision, a single collective task - to meet the conditions that by 2004 we can officially become a candidate for the European Community. We can do it - it is difficult, it entails great changes in institutions, in our mentality, in our habits, in our approach to problems - but we have a clear goal, we have a dream we can dream ... I call on you to participate, together with us democrats, in making that dream come true. (Djindjić 2005: 53) 34

However, there was no general political consensus on the "European Serbia" in that period. Diverse voices were heard. While politicians declared them right-wing, conservatives and nationalists (apart from accusing the ruling parties of selling out the country and acting under the influence of and at the bidding of foreign, adversarial powers) thought that in European integration Serbia was also threatened by the danger of losing its identity, and pointed to the EU's alleged requirement that Serbia "renounce itself" in order to meet its conditions for formal admission. The line of thought was the following: "We are already in Europe, we have always been Europe; the only question is how it treats us and whether it recognizes us as Europeans the way we are. Instead of admitting that we have always been part of it, Europe is abandoning us for its own current (political) interests." 35

The response to the issue that became current in public speech - that entry into the EU meant facelessness and loss of identity - is most concisely expressed as follows:

One of the major sources of frustrations with all Balkan nations, and particularly with the Serbs, is that they are imbued with wrong idea that

325 October 2000 became the symbolic date for Slobodan Milošević's stepping down from power; that is, for civil protests against the attempt to steal the election.

33 The Democratic Opposition of Serbia (DOS) coalition, which assumed power after the final defeat of Milosevićs regime in December 2000, was a broad coalition of eighteen parties.

34 The Tenth Congress of the SDS was held on 5 and 6 October 2001 at the Sava Center.

35 One such example is the interview with Dejan Medaković, art historian and president of the Serbian Academy of Sciences and Arts from 1999 to 2003, in the broadcast Europe and the Serbs, October, 2002 , RTS 2. 
accepting liberal, European, and Western principles means renouncing their own national identity and own nationalism. (Djurković 2002: 15)

Gradually, an idea started to be formulated in public speech that the Serbs can only be admitted to the EU “as Serbs" with a clearly defined cultural and national identity. Some politicians have expressed this clearly. For example, in June 2002, during the presidential electoral campaign, the People's Democratic Party (NDS) launched a poster with its (young and educated) president Slobodan Vuksanović under the slogan "Both Serbian and European.” Vojislav Koštunica, the president of Yugoslavia at that time, explained in an interview on the topic of the relationship between Serbian and European identity that "to Europe we can (go) only upright, as a nation with a first and last name." Moreover, Serbs can contribute to the "common European home" precisely by "not renouncing ourselves and our identity - otherwise we shall become a faceless mass that will get lost among many other nations and cultures." 36

During the course of 2003 and 2004, speech about Serbian identity in general, and even about Serbia's possible European identity, seemed to be temporarily suppressed from the public sphere. Nevertheless, this was exactly the time when the society-level consensus was achieved (at least in word, but later it turned out to be only temporary) that the EU path was Serbia's only possible option. ${ }^{37}$ Since then, all political actors have declared themselves to be pro-EU; however, it seems that speaking about this process and developing it has temporarily died out.

Public speech about Serbia in the EU picked up again during 2005, probably mostly due to the EU's decision to continue negotiations with Serbia and possibly accelerate them. Reactions in the press to the positive Feasibility Study in April 2005 were prevailingly euphoric, which was unusual. ${ }^{38}$ Some reviewers, however, observe that the EU was frequently mentioned in the media and public, but that still there was no essential development of the flow and process of integration to clarify these processes and bring them closer to people (Ćurguz Kazimir 2005; Sekulić 2005: 36-37). Therefore fears and animosity persist in parallel with occasional euphoria and rational attitudes. Thus among the Serbian public one can hear that, for example, Serbia should not go to Europe because "you should not go where nobody is waiting for or loves you," ${ }^{9}$ in the same time when "for Serbia and Montenegro, entry to the EU is certainly the only alternative" (Sekulić 2005: 37). The statement "Serbia needs Europe, but Europe needs Serbia as well" can be considered an expression of official discourse as well, bearing in mind that it was a brainchild of Prime

36 Black-White, July 2002, B-92.

37 The turning point in this respect was the tragic death of Prime Minister Djindjić, and perhaps the most influential was the fact that several hundred thousand people spontaneously attended his funeral.

38 "Evropo, stižemo" (Europe, We are Coming), Blic, 11 October 2005; "SCG jednom nogom u EU" (Serbia-Montenegro with One Leg in the EU), Danas, 4 October 2005; "Veliki dan" (The Big Day), Danas, weekend issue, 8 October 2005, "U Evropi smo svoj na svome” (In Europe We Are Coming into Our Own), Večernje novosti, 11 October 2005, and so on (http://digital.nb.rs).

39 The writer Brana Crnčević, Klopka, BK TV, February 2006. 
Minister Vojislav Koštunica (January 2006) on the occasion of a possible continuation of negotiations between Serbia and the EU. ${ }^{40}$

Vojislav Koštunica's period as the key political figure in the life of Serbia is characterized by strong hesitation toward the EU integration, and even a lull in public speech on this topic. Since December 2007, this issue has again become topical, both in political life and in broader public discourse. After concrete positive developments, the formation of a new government, and ratification of the Stabilization and Association Agreement in the Assembly of Serbia, in September 2008 relations between the EU and Serbia become a topic that almost no political broadcast, or even cultural or entertainment programs, could overlook during the next month or two. The question in public at that time was not whether Serbia should enter the EU, but what was hindering it and why the process was not progressing at a faster pace. Cooperation with The Hague and the recognition of Kosovo are particularly pressing issues, as real or alleged conditions for further integration, but from time to time there is also a question about domestic democratic development and maturity to enter the EU. The political elites have maintained that the Kosovo issue is open to manipulation, but it seems that this issue had increasingly less influence on people. Another topic, however, again raised the question about Serbia's determination to join Europe. This was the topic of the "gas arrangement" with Russia. It once again raised the issue of where Serbia's place is: in the West, in the East, or somewhere in between? All three options could be heard as answers to this question. In addition to polarization pro and contra the EU and the variant of both Serbia and Europe (to Europe, but only as Serbs, "with a first and last name"), it is therefore interesting to note some other discourse that attempts to overcome this issue, and that helps in understanding this area as a liminal zone that is neither East nor West, but a border zone, understood as an area of intensive communication, for example:

We are in between. We open the East to Europe, and it is fascinated by the

East. Once it was the Silk Road, now it is the oil road, whatever... If we

Westernize entirely, we will become faceless. ${ }^{41}$

Here it is interesting to cite one more example stating that the East-west issue is a false dilemma and that the Serbs, burdened with their own problems, have failed to notice that the world is no longer bipolar, and that the East itself has long and clearly been "going West." 42

In the typology of discourse about Serbia, the Balkans, and Europe, basic patterns are easily observed:

1. We do not need Europe (it rejects us, although we are, and always have been, Europe, the way we are - as Balkan people, Byzantines, Orthodox, anti-materialists, authentic, etc. - different, but not lower, and in some interpretations even above morally faltering Europe).

40 See: http://www.seio.gov.rs.

41 Interview with Mila Alečković-Nikolić, clinical psychologist, vice-president of the Association of Serbs in France, Jutarnji program, Studio B, January 2003.

${ }^{42}$ For example, Ključ, February 2006, RTS 1. 
2. Europe is necessary for us (Europeanization is the only path to modernity; or even: we cannot achieve modernity in any other way unless somebody from the outside imposes it on us through certain conditions).

3. We need Europe, but Europe needs us as well (Serbia is the "Europe of nations," which we should enter only "upright," with our own, clearly defined national identity).

4. We are between East and West and should derive an advantage from such a position.

One can also hear that the EU is something unachievable for Serbia, that it will never be able to meet its requirements, that the EU itself is having huge problems, and that it will fall apart before Serbia reaches it. ${ }^{43}$ It is also important that some public intellectuals are emphasizing that Serbs must rid themselves of the feeling that somebody from the outside is pushing or forcing them to enter the EU at any cost; they must understand the modernization of society as in their own interest, which they should achieve for their own sake. ${ }^{44}$

In addition to public discourse, the next issue highlighting the problem of European Serbia from another aspect is what the majority of people think about it; that is, what the reception of various discourses is among those to whom they are addressed. What do public opinion surveys say about this?

\section{PRO-EU PUBLIC OPINION BETWEEN WISHFUL THINKING AND REALITY}

Throughout this period, and according to some research dating back to the end of the 1990s, public opinion in Serbia has declared itself to be extremely pro-EU (cf. Baćević 2001: 13-19). ${ }^{45}$ In spite of all the problems that the Serbian people have passed through and tragedies that occurred, particularly during the 1990s, which exhausted the Serbs to the greatest extent and in all possible ways, and in spite of all the doubts in people's minds, public opinion toward joining the EU has been positive, topping 60\% during the last few years. ${ }^{46}$ However, researchers have noticed a certain disharmony between people's rational and emotional attitudes; in parallel with a rationally motivated desire to join the EU, respondents also feel an emotional resistance to the EU and the West: they perceive hostility, distrust, and fear, which was conceived in the period of the country's isolation and was particularly emphasized after the NATO bombing campaign. Researchers have noticed that the gap between the emotional and rational has not been resolved over the course of

43 While France and the Netherlands were rejecting the European constitution in referendums, a joke was being told in Belgrade that Serbia should be admitted to the EU once it fell apart.

44 For example, Vojin Dimitrijević, Director of the Belgrade Center for Human Rights, Proces TV, B92, February 2006.

45 It should also be noted that public opinion of the "second Yugoslavia" was characterized by an extremely low xenophobia and an extremely low presence of ethnic animosities (Lazić and Cvejić 2004: 59-60).

46 The highest percentage, $73 \%$, was shown in a study in the fall of 2003 . A more recent study, in December 2008, recorded a decline of 6\% in comparison to May 2008, but is still very high, at 61\% (http://www.seio.gov.sr). 
time. People are caught in the chasm between a feeling of distrust and even hostility, and the awareness that their interests and goals can be optimally achieved only by connecting with Western countries, nations, and organizations. ${ }^{47}$

Since June 2002, a quarterly check of the (pro-)EU mood of public opinion has been carried out in Serbia by means of an adjusted questionnaire also applied in the EU countries. ${ }^{48}$ This research also confirms that for many years support for EU integration has been very broad and mostly equally distributed, considering parameters such as age, education, gender, and place of residence; hence, for the majority of people, there is no alternative to EU membership and people's most important motive is a better life for the young generation. The obvious difference is, however, between wishes and reality; that is, between perceived and desired speed. Everybody would like faster integration, and young people (18 to 27 years old) are the least satisfied with the pace. In addition, in line with the gap mentioned above between emotional and rational feelings, Serbian distrust in EU institutions is often the highest in the region (Žeželj 2005). ${ }^{49}$

This lack of trust notwithstanding, the EU idea plays a very positive role in the belief system of the Serbian people. People's first associations with the EU are largely positive: better quality of life, a better living standard, travel opportunities, and so on. Negative associations are found among less than $5 \%$ of respondents. They are not dominant, but are persistent: distrust, ultimatums by the EU, unfair politics, and overly demanding requirements. The associative link of EU integration and benefit for young generations is related to the above. When asked "What does Europe mean to you personally?" 60\% of respondents answered with "Opportunities for young people" (Žeželj 2005).

EU enlargement is perceived as exclusively positive (growth of Europe's influence in the world, and peace and stability in Europe); two-thirds of people think that Serbia's membership is natural and that Serbia has a lot to offer Europe. People's expectations from membership are concrete and one-way: alleviation of the problems of everyday life, a solution to the problem of unemployment, and a rise in living standard. On the other hand, there is no great interest in actively participating in EU politics. The youngest segment of the population (age 15 to 29) hopes for the greatest personal benefits and has the fewest fears, particularly related to loss of identity (Žeželj 2005).

This strong support notwithstanding, there are fears as well: in general, the greatest fear comes from the price of entry and loss of national identity, especially language. This is generally characteristic of small countries and small languages. ${ }^{50}$ There are two sources of fear characteristic for the people of Serbia: loss of personal prospects (decline of living standards, impoverishment of the country, and job losses), and, generally, fear of the loss

47 Researchers claim that the external pressures to which the country was exposed were efficient, but that they also caused a controversial (negative) long-term effect (Baćević 2001: 8-9).

48 Surveys based on the adjusted Eurobarometer questionnaire are carried out by Strategic Marketing.

49 See: http://www.becei.org/EF0105/Iris_istrazivanje.htm.

50 Fears of large countries come from moving business to cheaper countries and excessive investment in new members (the price of integrating new and poorer countries). 
of cultural identity (i.e., language and national culture). If, however, cultural integration is observed as a two-way process, then the inclusion of a small Slavic culture into European heritage is perceived as something positive (Žeželj 2005). ${ }^{51}$

An interesting question is where such public support comes from, bearing in mind the constant contradictory messages people are exposed to in public discourse through the media. What do people really want and how do they even understand the EU, considering that the majority of respondents characterize themselves as rather poorly informed, and that among the Serbian public, and particularly in the media, EU topics (even when positively covered) mostly remain at the level of abstract calls for unification, better living standards, and abolition of visas, and at the same time neglect deeper analysis of the European situation and serious plans for association (Žeželj 2005). What information do relatively uninformed respondents base their choices on?

Researchers observe that support for association extensively overlaps with people's reform orientation. Even so, as much as 20 to $25 \%$ of people think that reforms are not the necessary first step on the path to the EU. Their support for admission is only lip service; that is, they support painless association, based on unrealistic expectations or lack of information. Some people's attitudes are characterized by unrealistic goals and an insufficient understanding of the essence of association. People rationally understand that the path to the EU must be long, but they are not entirely aware of the volume of preceding reforms, and they expect it to be tomorrow, at the same time showing unreadiness to pay the full price of transition (Baćević 2001). Simultaneously, people have contradictory feelings about the West, and they do not believe in its good intentions or its institutions (Žeželj 2005).

Analysts conclude that the idea of the EU has an important positive role in the belief system of the Serbian people; from one survey to another (up to the most recent one) it has been the only important generator of optimism. It seems that this (sometimes even exaggerated) optimism and desire for the EU here and now that would allegedly solve all of Serbia's problems represents compensation for a burdensome everyday life, which for the majority of people means poverty, uncertainty, stress, and fear, all of which have lasted for too long already, and the erroneous assumption that it is possible to again live as carefree and protected as during the 1970s in the "second Yugoslavia," and that life in the EU means exactly the same thing. ${ }^{52}$ On the one hand, this opened a way to a sort of demagogy: "In recent years, from the time of the 'democratic revolution' of 2000, the term EU has started to be used in political practice with similar intentions as other mythologems of the twentieth century had been used (the myth of brotherhood and unity, the myth of Great Serbia, or the global conspiracy against the Serbs)" (Lukić and Jovanović 2004: 5). On the other hand,

51 Regarding ambivalence in constructing the image of Europe among the student population in Belgrade, see Radović (2006).

52 Although dissenting from such a conclusion, another study also points to the fact that the Yugoslavia of the 1970s is the frame of reference when people think about good, high-quality life (Golubović et al. 2003: 99-101). 
however, EU entry is Serbia's only articulated goal for the future. In difficult daily life and an exhausting transition, association with the EU is a realistic, defined goal that offers a concrete, solid stronghold for the coming times and some orientation, although a distant one: a concrete goal, a concrete moment in time, and the act of admission representing the achievement of that goal.

However, the reality of today's society in Serbia - the reality of a destroyed society, massively impoverished and disoriented - raises the question of how achievable joining the EU is for Serbia, independent of the issue of whether the public desires it and the elites manipulate it. Furthermore, the decline in support for joining the EU indicates fatigue and lack of trust in achieving that goal. ${ }^{53}$

\section{IN LIEU OF A CONCLUSION: ONE STEP FORWARD, TWO STEPS BACK}

Based on everything said so far, it is notable that Serbia's path to the EU is characterized by controversies at many levels, from imaginary to realistic ones. Probably because of this discrepancy between wishes and reality, between what is spoken and what is done, the relationship between Serbia and the EU in public discourse and public opinion is complex and largely ambivalent. It involves the idea that Serbia is already in Europe, the way Serbia is, representing the very essence of Europeanism, or that Serbia should be admitted to the EU tomorrow, thus instantly solving all of the problems, even though there are significant doubts whether EU standards are achievable for Serbia at all, or rejection of the West and the EU as something essentially alien and hostile to Serbia. Public opinion expresses overall support for a European Serbia, but at the same time manifests a division between the emotional and rational perception of Europe, confusion, and poor information in relation to what $\mathrm{EU}$ integration really means and a superficial desire to enter the $\mathrm{EU}$ as soon as possible, but without the actual will to pay the price of that endeavor. Furthermore, there is an already an obvious deterioration in people's mood toward EU integration, which is still not sufficiently taken into account by politicians and interpreters of social processes, and which might mean both disappointment in the allegedly hostile EU itself, disappointment in domestic politicians and their most recent hesitation on the path to EU integration, transitional fatigue, and loss of trust in the EU as a savior because the EU itself has recently been gripped by a deep and uncertain economic crisis.

Public desire for a normal life, the establishment of basic order, and the creation of

53 At a press conference held in late February 2009 at the Media Center in Belgrade by the nongovernmental organization European Movement for Serbia, it was judged that Serbian public opinion has recently been characterized by three erroneous beliefs about the relationship between Serbia and the EU: that it requires Serbia to renounce Kosovo, that it poses ever new and increasingly difficult conditions because the EU in fact does not want Serbia, and that the economic crisis will slow down and even stop the EU integration processes. These erroneous assumptions have led to a decline of trust in efforts to join the EU. 
opportunities for themselves and their children, as well as the presence of EU institutions in political and everyday life to a much greater extent than ever before, the declared decisiveness of the ruling elites on their commitment to EU integration, and the fact that EU negotiations are still ongoing (albeit with interruptions) - all of this leaves open a certain possibility that substantial progression in Serbia towards a more decent, organized, and successful society might happen this time. The crucial question, however, is whether this will prove to be sufficient because Serbian society is a society with deep and complex problems that require huge efforts to solve. Society and the social elites are divided into Europhiles and Europhobes, and with rare exceptions it can be assumed that both the "pro" and "con" sides are most often insufficiently well grounded. At the same time, serious questions remain open, such as whether Serbian society is not only impoverished and disoriented, but also a society without clear rules of the game, without an idea of the public good, without enough transparency, in which small, interrelated interest groups endlessly drain the country's resources without any public accountability. Therefore funding is slowed down and circuitous, the pro-EU path is not enthusiastically being followed, and no serious alternative has been created for it. Europeanization is very seldom described as a step forward to modernity that is important for Serbians themselves; no serious internalization of European values and standards for the sake of society itself is being worked out. Instead, with rare exceptions, the notion of the EU is used at a superficial, populist level, be it pro or con. People's patience is at an end, society's resources are drained, and the danger of one more failure of insufficiently well-embedded modernization efforts in Serbian history is in the air.

\section{REFERENCES}

Antonić, Slobodan

2002 Zarobljena zemlja. Srbija za vlade Slobodana Miloševića. Beograd: Otkrovenje.

2003 Nacija u strujama prošlosti. Beograd: Čigoja štampa.

Antonijević, Dragana

2007 Karadjordje i Miloš. Izmedju istorije i predanja. Beograd: Srpski genealoški centar, Odeljenje za etnologiju i antropologiju Filozofskog fakulteta (Etnološka biblioteka; 32).

Baćević, Ljiljana

2001 Srbi iEvropa. Javno-mnenjskepretpostavke integrisanja Srbije u evropsku zajednicu. Beograd: Centar za antiratnu akciju.

Bakić-Hayden, Milica

1998 Reprodukcija orijentalizma. Primer bivše Jugoslavije. Filozofija i društvo 14: 101-119.

Bakić-Hayden, Milica and Robert Hayden

1992 Orientalist Variations on the Theme "Balkans": Symbolic Geography in the Recent Yugoslav Cultural Politics. Slavic Review 51 (1): 1-15.

Bolčić, Silvano

1993 Sociologija i ,jugoslovenska svakodnevica“ početkom devedesetih. Sociološki pregled 1-4: 27-37. 
Bolčić, Silvano and Anđelka Milić (eds.)

2002 Srbija krajem milenijuma. Razaranje društva, promene i svakodnevni život. Beograd: Institut za sociološka istraživanja Filozofskog fakulteta.

Bolčić, Silvano and Anđelka Milić

2002 Srbija na kraju milenijuma. Kakvo je to drustvo? In: Bolčić and Milić (eds.) 2002, 5-14.

Chirot Daniel (ed.)

1991 The Origins of Backwardness in Eastern Europe: Economics and Politics from the Middle Ages until the Early Twentieth Century. Berkeley: University of Califronia Press.

Ćurguz Kazimir, Velimir

2005 Kako vidimo Evropu. Evropski forum (monthly on European integration), No. 1, January 2005 (supplement to the Vreme weekly, of January 27, 2005).

Đinđić, Zoran

2005 Put Srbije u Evropu (Ž. Ivanović, ed.). Beograd: Draslar Partner.

Đurković, Miša

2002 Nacionalni identitet i liberalna demokratija. In: Jael, Tamir, Liberalni nacionalizam. Beograd: Filip Višnjić (Libertas), 5-15.

Domenak, Žan Mari

1991 Evropa. Kulturni izazov. Beograd: Biblioteka XX vek, Knjižara Plato (Biblioteka XX vek; 74).

Dragović-Soso, Jasna

2004 Spasioci nacije. Intelektualna opozicija Srbije i oživljavanje nacionalizma. Beograd: Fabrika knjiga (Edicija Reč; 34).

Fleming, Ketrin E.

2001 Orijentalizam. Balkan i balkanska istoriografija. Filozofija i društvo18: 11-32.

Golsvorti, Vesna

2005 Izmišljanje Ruritanije. Imperijalizam mašte. Beograd: Geopoetika.

Golubović, Zagorka, I. Spasić, and Đ. Pavićević

2003 Politika i svakodnevni život. Srbija 1999-2002. Beograd: Institut za filozofiju i društvenu teoriju (Biblioteka Disput).

Jansen, Stef

2001 Svakodnevni orijentalizam. Doživljaj „Balkana“/ „Evrope“ u Beogradu i Zagrebu.

Filozofija i društvo18: 33-71.

Jezernik Božidar

2007 Divlja Evropa. Balkan u očima putnika sa Zapada. Beograd: Biblioteka XX vek, Knjižara Krug (Biblioteka XX vek; 164).

Lazić, Mladen

1994 Sistem i slom. Beograd: Filip Višnjić.

Lazić, Mladen (ed.)

1994 Razaranje društva. Beograd: Filip Višnjić.

2000 Račji hod. Srbija u transformacijskim procesima. Beograd: Filip Višnjić. 
Lazić, Mladen and Slobodan Cvejić

2004 Promene drušstvene strukture u Srbiji. Slučaj blokirane post-socijalističke transformacije. In: Milić (ed.) 2004, 39-70.

Lukić, Marija and Slađana Jovanović

2004 Korak bliže ili korak dalje od Evrope. Beograd: Glas razlike.

Malešević, Miroslava

2008 Nasilje identiteta. In: Divac, Zorica (ed.), Kulturne paralele. Beograd: Etnografski institut SANU (Zbornik EI SANU; 25), 1-34.

Milić, Anđelka (ed.)

2004 Društvena transformacija i strategije društvenih grupa. Svakodnevica Srbije na početku trećeg milenijuma. Beograd: Institut za sociološka istraživanja Filozofskog fakulteta.

Noris, Dejvid

2002 Balkanski mit. Beograd: Geopoetika.

Obradović Popović, Olga

2006 Koreni antimoderne političke kulture u Srbiji. In: Lilić, S. (ed.), Pravni kapacitet Srbije za evropske integracije. (prir. S. Lilić). Beograd: Pravni fakultet Univerziteta u Beogradu (Zbornik radova; 1), $151-160$.

Perović, Latinka

2006 Srbija u modernizacijskim procesima XIX i XX veka. In Perović, Latinka (ed.), Srbija u modernizacijskim procesima XIX i XX veka 4. Žene i deca. Beograd: Institut za noviju istoriju Srbije (Helsinške sveske; 23), 7-32.

Pjanović-Luković Olga

1990 Srbinarod najstariji. 1-2. Beograd: Dosije.

Prelić, Mladena

2006 Korak bliže Evropi ili korak dalje od nje. Srbija u potrazi za evropskim identitetom na početku XXI veka. In: Divac, Zorica (ed.), Svakodnevna kultura u postsocijalističkom periodu u Srbiji i Bugarskoj. Balkanska transformacija i europska integracija. Beograd: Etnografski institut SANU (Zbornik EI SANU; 22), 29-50.

Radović, Srđan

2006 Kulturna konstrukcija predstava o Evropi u Srbiji (MA thesis, manuscript, library of the Department of Ethnology and Anthropology of the Faculty of Philosophy in Belgrade).

Ranković, Larisa

2005 Analiza. Štampa u Srbiji o evropskim integracijama tokom 2005. godine (http://digital.nb.rs/eu/).

Sajd, Edvard V.

2000 Orijentalizam. Beograd: Čigoja štampa; Zemun: Biblioteka XX vek (Biblioteka XX vek; 112).

Sekulić, Ljubiša

2005 Podrška bez sadržine. Helsinška povelja 79-80 (Jan.-Feb. 2005): 36-37.

Stojanović, Dubravka

2005 Ulje na vodi, politika i društvo u modernoj istoriji Srbije. In: Stojičić, Slobodanka (ed.), Srbija 1804-2004. Društvo, ekonomija, država, pravo, politika, kultura, religija. Zbornik radova sa naučnog 
skupa održanog 20-23. oktobra 2004. godine na Pravnom fakultetu u Nišu. Niš: Pravni fakultet, $115-149$.

Stojanović, Trajan

1997 Balkanski svetovi. Prva iposlednja Evropa. Beograd: Equilibrium.

Subotić, Milan

2003 Tradicija podela. Prilozi simboličkoj geografiji evropskog prostora. In: Savić, Mile (ed.), Integracija $i$ tradicija /Integration and Tradition. Beograd: Institut za filozofiju i društvenu teoriju/Institute for for Philosophy and Social Theory.

Todorović, Ivica

2005 Mitska istina Srba. Beograd: Zvonik.

Šmale, Volfgang

2002 Istorija evropske ideje. Beograd: Clio.

Todorova, Marija

1999 Imaginarni Balkan. Zemun: Biblioteka XX vek; Beograd: Čigoja štampa (Biblioteka XX vek; 103).

Velikonja, Mitja

2007 Evroza. Kritika novog evrocentrizma. Beograd: Biblioteka XX vek, Knjižara Krug (Biblioteka XX vek; 163).

Wolff, Larry

1994 Inventing Eastern Europe. Stanford: Stanford University Press.

Zundhausen, Holm

2008 Istorija Srbije, od 19. do 21. veka. Beograd: Clio.

Žeželj, Iris

2005 Za bezbolnu integraciju. Evropski forum, January 1st, 2005 (www.becei.org/EF0105/Iris_istrazivanje.htm).

Živković, Marko

2001 Nešto između. Simbolička geografija Srbije. Filozofija i društvo 18: 73-110.

\section{INTERNET SOURCES}

www.becei.org - Web site of the NGO Beogradski centar za evropske integracije. www.seio.gov.rs - Web site of the Government's EU Integration Office.

www.pescanik.net - Web site of the Radio broadcast Pescanik (Radio B92).

\section{KORAK NAPREJ, DVA NAZAJ. SRBSKA POT V EVROPO NA ZAČETKU 21. STOLETJA}

Vzadnjih desetletjih 20. stoletja je bilo v večini držav Vzhodne Evrope relativno lahko doseženo soglasje o neogibnosti "poti v Evropo" oz. o evropski integraciji, $v$ Srbiji pa kakor da politične in intelektualne 
elite še vedno oklevajo pri dokončni odločitvi o tem. V tem delu so na primeru razprav v javnosti kakor tudi javnega mnenja o tem vprašanju predstavljene dileme o evropski ali neevropski identiteti Srbije in možnostih njene vključitve v Evropsko unijo. Analiza javnega diskurza je zasnovana na sistematičnem sledenju izbranih televizijskih medijev v naključno izbranih časovnih presekih v letih 2002-2009. Poleg tega je prispevek v veliki meri zasnovan na "udeleženskem znanju " avtorice kot pripadnice srbske družbe.

Vprašanje razmerja med Srbijo in Evropo ni novo, saj nekako označuje vso sodobno srbsko zgodovino od začetka 19. stoletja. Čeprav ga je mogoče povezati s simbolično geografijo in hegemonističnimi diskurzi, ki jih je razviti Zahod vsilil Vzhodu in Balkanu, ga je prav tako mogoče povezati tudi s konceptoma "nedokončana modernizacija in "relativna zaostalost", ki problem premakneta simbolične nazaj na realno raven. Spoznanje o relativni zaostalosti, ki globoko frustrira srbske elite in ki se zdi težko presegljiva, izziva srbsko družbo vse do danes in iz nje ustvarja razdeljeno družbo oz. družbo brez soglasja o temeljnih vrednotah in ciljih. Razdeljenost označuje tudi sočasna stališća in diskurze o Srbiji in Evropi, ko gre za razmerje z Evropo v obliki vprašanja o pridružitvi Srbije Evropski uniji. Vprispevku sta predstavljena kratek družbeno-politični kontekst in pregled novejših stikov med Srbijo in Evropo od konca 80. let prejšnjega stoletja do leta 2008. Zadnje desetletje 20. stoletja, leta vladavine Miloševićevega nacionalističnega in populističnega režima, vojna na ozemlju bivše Jugoslavije, osamitev in vojna proti paktu NATO so iz Srbije ustvarile razdejano in obubožano družbo, ki ne more zlahka poiskati rešitev svojih številnih problemov. V 90. letih ustvarjena nepresojna vez med politiko (in določenimi deli oblasti), gospodarstvom in kriminalom, ki do danes ni povsem pretrgana, je za družbo izjemno obremenjujoča ter je verjetno najmočnejša zavora za njen razvoj. Spremembe, do katerih je prišlo leta 2000 s padcem Miloševićevega režima, so odprle vprašanja o nadaljnjih smereh z novo perspektivo. Po letih osame in spopadov Srbije s svetom se je mdr. tudi vključevanje v EU pokazalo za realno dosegljiv cilj. V članku se govori o razpravah v javnosti, ki so se v tem času pojavile o približevanju EU, kakor tudi v odzivih nanje v javnem mnenju. Razprave je mogoče razdeliti na štiri skupine: 1. Evrope ne potrebujemo, izgubila je svoje prave vrednote, prava Evropa smo mi; 2. Evropa nam je neogibna, brez njene podpore se ne moremo rešiti iz svojih problemov, 3. Evropo potrebujemo in mi smo ji potrebni - v EU moramo vstopiti, vendar "opremljeni«, z jasno nacionalno identiteto; 4. smo med vzhodom in zahodom in iz tega položaja lahko potegnemo koristi. Vzadnjem razdelku teče beseda o tem, kako se državljani Srbije na podlagi raziskav javnega mnenja odzivajo na samo problematiko in razprave o razmerju med Srbijo in Evropo. Z nekaterih vidikov so njihova stališča mnogo zrelejša od stalǐ̌č političnih in intelektualnih elit, z drugih pa tudi precej naivnejša. Pa vendar je mogoče skleniti, da je edini stalni gonilni dejavnik, ki usmerja k Evropi, želja navadnih državljanov za mirno, stabilno in bolj urejeno življenje oz., še bolj-za takšno življenje njihovih otrok. Kljub temu ostaja vprašanje priključevanja Srbije Evropi (EU) še odprto, odgovor nanj pa negotov.

Dr. Mladena Prelić, Etnografski inštitut SANU, Knez Mihajlova

36/IV, RS - 11000 Beograd, Mladena.Prelic@ei.sanu.ac.rs 
